\title{
Carbon increase and soil physical improvement in an onion no-tillage system
}

\author{
Diego Fernando Roters ${ }^{1 *}{ }^{\oplus}$, Álvaro Luiz Mafra ${ }^{1} \odot$, Freedymann Ferreira da Cunha ${ }^{1} \odot$, \\ Roberta Padilha Macedo ${ }^{1}$, Caroline Perez Lacerda da Silveira ${ }^{1}$, Gregory Kruker $^{1}[0$ \\ ${ }^{1}$ Santa Catarina University State, Lages, SC, Brazil. E-mail: diegoroters@gmail.com; alvaro.mafra@udesc.br; freedymann@gmail.com; roberta101.pm@gmail.com; \\ carolineplacerda@gmail.com; gregorygregory10@hotmail.com
}

ABSTRACT: The no-tillage vegetable planting system (NTVPS) is a way to integrate production and soil conservation. The study was conducted on a Haplic Cambisol in the municipality of Alfredo Wagner - SC, in 2017. It aimed to evaluate physical attributes and carbon fractions of soil under consolidated NTVPS cultivation for 10 years as compared to thirty-year conventional tillage (CT) and a native forest (NF) on a Haplic Cambisol. The aspects evaluated were: total organic C, soil density (SD), total porosity (TP), macropores, micropores, aggregate stability, resistance to mechanical penetration (PR) and water infiltration into de soil. CT showed higher SD as compared to NTVPS, mainly in the 5 to 10-cm layer, whereas PR was higher in NTVPS, particularly in the 5 to $10-\mathrm{cm}$ layer, thus exceeding the critical limit for this variable. Nevertheless, NTVPS showed greater accumulated water infiltration and infiltration stabilization at 20 minutes. In the native forest, infiltration was lower than that in NTVPS, and the lowest constant infiltration values occurred in CT from the beginning of the test. The NTVPS treatment showed greater efficiency in carbon storage and aggregation as compared to CT, therefore, favorable structural conditions for plant growth.

Key words: conservation management; soil cover; soil quality

\section{Incremento de carbono e melhoria física do solo em sistema de plantio direto de cebola}

RESUMO: O sistema de plantio direto de hortaliças (SPDH) é uma maneira de conciliar produção e conservação do solo. 0 estudo foi conduzido no município de Alfredo Wagner - SC em 2017 sobre um Cambissolo Háplico. 0 objetivo da pesquisa foi avaliar atributos físicos e frações de carbono do solo em cultivo em SPDH consolidado de 10 anos em comparação ao plantio convencional (PC) com 30 anos e à mata nativa em condições de um Cambissolo Háplico. As avaliações foram o $\mathrm{C}$ orgânico total, densidade do solo (DS), porosidade total (PT), macroporos, microporos, estabilidade de agregados, resistência à penetração mecânica (RP) e infiltração de água no solo. O PC apresentou maior DS em relação ao SPDH, principalmente na camada de 5 a $10 \mathrm{~cm}$, já a RP foi maior em SPDH, principalmente na camada de 5 a $10 \mathrm{~cm}$, superando o limite crítico desta variável. Apesar disso, o SPDH apresentou maior infiltração acumulada de água e estabilização na infiltração aos 20 minutos. $\mathrm{Na}$ mata nativa a infiltração foi inferior a SPDH e os menores valores de infiltração constante ocorreram no PC desde o início do teste. $\mathrm{O}$ tratamento com SPDH demonstrou maior eficiência no armazenamento de carbono e agregação em relação ao PC, evidenciando condições estruturais favoráveis ao crescimento vegetal.

Palavras-chave: manejo conservacionista; cobertura do solo; qualidade do solo

\footnotetext{
* Diego Fernando Roters - E-mail: diegoroters@gmail.com (Corresponding author)

Associate Editor: Yuri Jacques Agra Bezerra da Silva
} 


\section{Introduction}

Onion (Allium cepa) production in Brazil is an important socioeconomic activity for the country, significantly contributing to the generation of income and jobs.

Santa Catarina state (SC) accounts for approximately $30 \%$ of the national onion production, thus being its largest producing state (Gugel, 2018). However, there are still challenges regarding soil management, since the conventional tillage system (CT) is often adopted, which involves mechanization and intense soil mobilization, with high demand and use of external inputs and water, generating negative impacts, such as compaction, reduced levels of organic matter (OM) and erosion, and the loss of water and topsoil layers (Loss et al, 2015).

In this regard, since the early 1990s, the no-tillage vegetable planting system (NTVPS) has been characterized as a theoretical-methodological praxis in SC, consisting of technical-scientific and political-pedagogical axes, aiming at the agroecological transition of agricultural systems to reduce the physical, biological, and chemical degradation caused by the use of plowing and rotary hoeing in vegetable cultivation areas, highlighting the sloping areas in the upper Itajaí River valley region (Arl et al., 2019).

The sustainable management of soils and water in NTVPS, promoting the health of cultivated plants, aims to optimize the expression of genetic potential and minimize nutritional, salinity, temperature, light, $\mathrm{pH}$, and oxygen-diffusion-speed stress, among others, based on the following principles: minimum soil disturbance, restricted to the planting bed or furrow; the diversification and arrangement of species through rotation, succession and intercropping; and the maintenance of plant residues from cover crops throughout the crop cycle (Freitas, 2002).

NTVPS in onion crops begins with seedling production in beds, and then the seedlings are transplanted into furrows prepared by equipment adapted for cutting the plant biomass present on the soil, which is restricted to the planting rows (Loss et al., 2017). The improvement in the quality of soils cultivated under NTVPS is dependent on the addition of biomass and permanent soil protection (Kurtz et al., 2019), with phytomass production by cover plants maintained on the soil surface, for nutrient and carbon cycling in the soil.

Studies by Loss et al. (2015) report that NTVPS reduced soil loss by $95 \%$, when compared to the conventional tillage system (CT), and by $88 \%$, when compared to planting with reduced preparation, showing a greater mean weightdiameter (MWD) of aggregates in NTVPS. The ratio of organic $C$ in NTVPS increased from the first years of implementation with a consequent increase in water infiltration due to the formation of a more porous profile from the adoption of the crop rotation system (Patra et al., 2019), resulting in improved soil structure (Melo et al., 2019).

This study aimed to evaluate soil physical attributes and organic carbon in a consolidated 10-year NTVPS crop compared to 30-year CT and native forest, under commercial onion cultivation conditions on a fine-loamy to fine textured Haplic Cambisol.

\section{Materials and Methods}

The study was conducted in a commercial production area located in the municipality of Alfredo Wagner - SC, under conventional tillage conditions (CT) for 30 years (Figure 1a), no-tillage (NTVPS) onion planting for 10 years (Figure $1 \mathrm{~b}$ ), and non-anthropized native forest (NF).

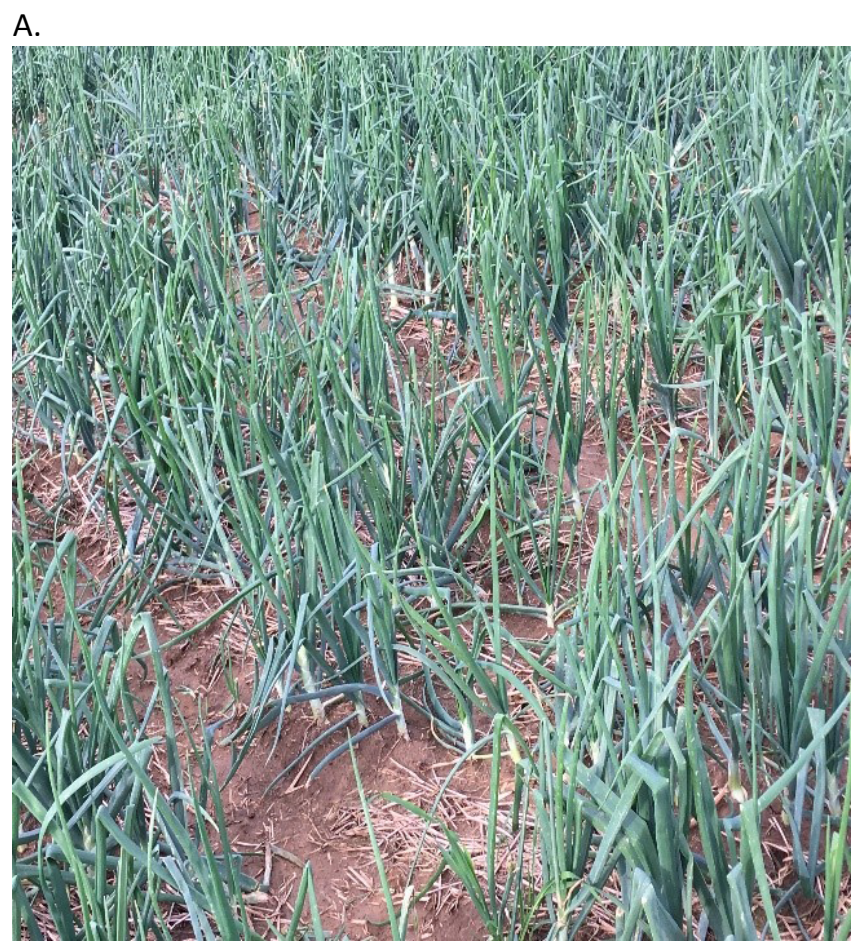

B.

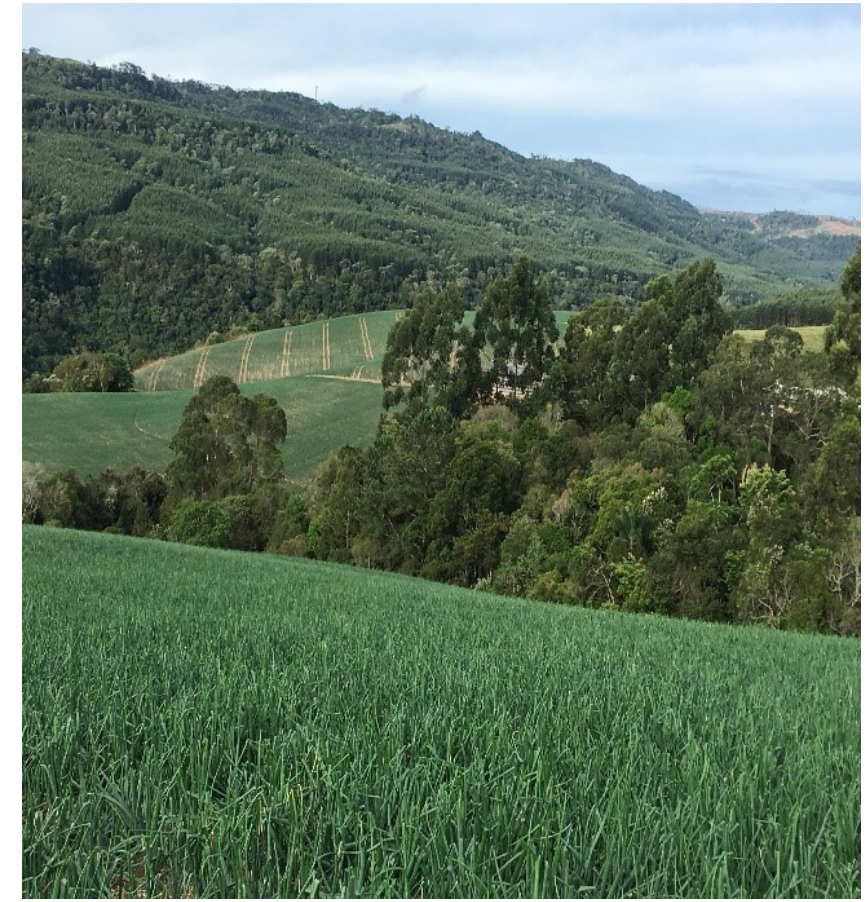

Figure 1. Commercial onion production area under two production systems: CT and NTVPS. 
The areas are adjacent and have similar relief and soil conditions, with the central position located at coordinates $27042^{\prime} 01^{\prime \prime} \mathrm{S}$ and 49.20'01" W, at an altitude of $750 \mathrm{~m}$. The region's climate is Cfa, according to the Köppen classification, that is, humid subtropical with hot summers, an average annual temperature of $18.3^{\circ} \mathrm{C}$ and average annual precipitation of $1,568 \mathrm{~mm}$. The soil was classified as Haplic Cambisol, with a fine loamy texture in NTVPS and CT, and a fine texture in the native forest area, using the pipette method described by Day (1965) and Gee \& Bauder (1986) (Table 1).

The NTVPS area was initially used with conventional onion cultivation until 2006, and in the same year, a change in management was initiated, with the planting of soil cover crops every onion intercrop. Onion cultivation with crop rotation occurs every two years, with the use of cover crops, namely: crotalaria, marmalade grass, mucuna, and black oat. In the CT area, beans or corn are grown during the onion offseason. The NF area is maintained as preservation, without anthropic disturbance.

Total soil preparation in the NTVPS area was last performed using a rotary hoe in July 2006. In the conventional area, a rotary hoe is utilized for onion cultivation, and for the other crops, a plow and a leveling harrow.

For the collected soil area with a disturbed structure in the three study systems, delimitation was performed by a $15 \times 25-\mathrm{m}$ sampling grid in two transects at collection points every 5 meters, at two depths $(0-5$ and $5-10 \mathrm{~cm})$. The samples with undisturbed structure were collected in duplicate from each plot using volumetric rings measuring $5 \mathrm{~cm}$ in height and $6 \mathrm{~cm}$ in diameter.

In the laboratory, the undisturbed samples were initially saturated with water on trays by capillarity, and the mass of the set used, consisting of the ring, protective material and saturated soil, was determined. The saturated rings were subjected to water tensions of 1,6 , and $10 \mathrm{kPa}$ on a sand column table until moisture balance was reached, and the mass was determined at each tension applied. Then, the rings with undisturbed structure were dried in an oven at 105 oC for 48 $h$, according to the method described by Claessen et al. (1997).

Total porosity (TP) was estimated by the difference between saturated soil mass (mSaturated) and dry soil mass

Table 1. Particle-size analysis of a Haplic Cambisol in commercial onion production systems and a native forest.

\begin{tabular}{|c|c|c|c|}
\hline \multirow{2}{*}{$\begin{array}{l}\text { Depth } \\
(\mathrm{cm})\end{array}$} & Clay & Silt & Sand \\
\hline & \multicolumn{3}{|c|}{$\left(\mathrm{g} \mathrm{kg}^{-1}\right)$} \\
\hline \multicolumn{4}{|c|}{ NTVPS } \\
\hline $0-5$ & 375.8 & 335.6 & 288.6 \\
\hline $5-10$ & 376.5 & 331.8 & 291.6 \\
\hline \multicolumn{4}{|c|}{ CT } \\
\hline $0-5$ & 366.5 & 239.1 & 394.4 \\
\hline $5-10$ & 371.4 & 222.7 & 405.9 \\
\hline \multicolumn{4}{|c|}{ NF } \\
\hline $0-5$ & 235.3 & 314.4 & 450.3 \\
\hline $5-10$ & 227.1 & 316.5 & 456.4 \\
\hline
\end{tabular}

Note: NTVPS: No-tillage vegetable planting system; CT: Conventional tillage; NF: Native Forest.
(mDS), considering the ring volume. Microporosity was obtained by the difference in saturated soil mass, and, after the $6 \mathrm{kPa}$ tension, the macropore volume was obtained on a sand tension table (Claessen et al., 1997) by the difference between TP and microporosity. Soil density (SD) was obtained by the volumetric ring method through the dry mass to volume ratio (Blake \& Hartge, 1986).

Mechanical resistance to penetration was evaluated using a Marconi bench top penetrometer, model MA 933, with a 4-mm diameter cone, which was introduced into the soil samples up to a depth of $4.5 \mathrm{~cm}$, at a constant speed of 30 $\mathrm{mm} \mathrm{min}^{-1}$ and readings every $1 \mathrm{~s}$.

The samples with undisturbed structure, removed by a metal spatula, were placed in plastic bags to conserve the soils structure, for subsequent separation of aggregates from 4.75 to $8.00 \mathrm{~mm}$ to determine the stability of aggregates by the wet sieving method, according to Kemper \& Chepil (1965).

The analysis of the size and stability of aggregates was determined by the wet sieving methodology, described by Claessen et al. (1997), using 25-g samples of aggregates in duplicate. They were arranged in the sieve sets of 4.76; 2.00; 1.00 and $0.250 \mathrm{~mm}$, placed in the vertical oscillation equipment previously filled with water up to $1 \mathrm{~cm}$ above the level of the sieve sets. The aggregates were submerged in water for 10 minutes for resting and moistening, and after that period, the equipment was turned on and oscillated for 10 minutes. The material retained on each sieve was transferred to aluminum cans and placed in an oven at 105 으 for 24 hours, after which the material was weighed to perform the calculations.

The samples with an altered structure were air dried, ground, and sieved through a 2-mm mesh sieve to determine organic carbon (OC). Subsequently the samples were ground in a ball mill until they passed through a $0.053-\mathrm{mm}$ sieve. Carbon determination was performed by a dry-combustion elemental analyzer (TOC). Particulate organic carbon (POC) was analyzed after physical fractionation as described by Cambardella \& Elliott (1992).

Mineral-associated carbon (MAC) was obtained by subtracting the POC value from the total organic carbon (TOC). The soil organic- $C$ stock was calculated by the equivalent-mass method, based on Guareschi et al. (2012).

The carbon management index (CMI) was calculated according to the methodology described by Blair et al. (1995). The carbon efficiency index (CEI), the lability index (LI) and carbon lability (L) were calculated according to the methodology described by Vieira et al. (2007).

Water infiltration into the soil was determined by the concentric-ring method, following the procedure described by Forsythe (1975), and the total sheet of infiltrated water $(\mathrm{mm})$ and the final rate of water infiltration into the soil were obtained, the latter represented by the basic rate of water infiltration $\left(\mathrm{mm} \mathrm{h}^{-1}\right)$, obtained under saturated soil conditions.

The evaluation time was $90 \mathrm{~min}$, with a 1-min interval for the first five evaluations (5 $\mathrm{min}$ ), 5-min intervals until the next $25 \mathrm{~min}$ (30 $\mathrm{min}$ ), and a subsequent 10-min interval until completion at $90 \mathrm{~min}$. The infiltration readings were fitted 
to Horton's exponential equation as described by Prevedello (1996).

The results obtained per layer were analyzed using Bartlett's test for homogeneity of variance according to Sokal \& Rohlf (1995) and the Shapiro-Wilk normality test at 5\%. When the assumptions for the analysis were met, regression and the Scott-Knott (Scott \& Knott, 1974) cluster likelihood test were carried out. The statistical analyses were performed using the Action and Sigmaplot 11.0 software programs.

\section{Results and Discussion}

In NTVPS, $72 \%$ of the aggregates were retained on the largest-diameter sieve, with a mean weight-diameter (MWD) of $5.04 \mathrm{~mm}$ in the $0-5-\mathrm{cm}$ layer and $4.98 \mathrm{~mm}$ in the $5-10-\mathrm{cm}$ layer, indicating high aggregate stability and a statistical difference between NTVPS/NF treatments compared to CT (Table 2).

In $\mathrm{CT}$, only $36.2 \%$ of the aggregates were retained on the largest-diameter sieve, which shows soil disaggregation in comparison to the NTVPS area (Table 2). The breakdown of aggregates is related to periodic soil preparation for each crop, the absence of cover crops and the use of a simplified crop succession with lower biomass production (Jordán, et al., 2010).

The difference shown between the management systems adopted can be explained by the use of crop rotation and by not mobilizing the soil, favoring the formation and stabilization of aggregates.

NTVPS is based on the use of cover crops with a high phytomass production from their above-ground mass (Mafra et al., 2019; Nicholls et al., 2019), alone or in combination, using management equipment often adapted to the local reality, promoting cover crop management and physical protection of the soil surface (Loss et al., 2015; 2017), which are systems that tend to show better results than CT in the first years.

Another point to be highlighted in NTVPS is the large number of roots that are present and promote greater soil exploration (Mafra et al., 2019), contributing to greater aggregate stability, in addition to increasing microbial activity, thus releasing nutrients and accumulating organic matter in the surface layers of the soil $(0-10 \mathrm{~cm}$ ) (Loss et al., 2015).

Because grasses have a fasciculate root system that is renewed relatively quickly, their use in crop rotation systems, such as NTVPS, is more efficient in the maintenance and formation of aggregates than are leguminous plants (Loss et al., 2015). Plants with a pivotal root system have the most aggressive characteristic in relation to soil depth, which explains the results shown in NTVPS.

The similar stability of aggregates in NTVPS and NF can be explained by the high phytomass production, increasing microbial activity, releasing nutrients and accumulating $\mathrm{OM}$ in the surface layers $(0-10 \mathrm{~cm})$, which consequently increased the stability of aggregates in these two areas (Lovato et al., 2004). The highest total porosity (Table 3 ) was found in the NF area with $0.59 \mathrm{~m}^{3} \mathrm{~m}^{-3}$ in the $0-5-\mathrm{cm}$ layer and $0.57 \mathrm{~m}^{3} \mathrm{~m}^{-3}$ in $5-10 \mathrm{~cm}$, and this volume can be explained by the fact that it is an environment with a greater diversity of species and permanent presence of roots.

Table 2. Percentage of aggregates of a Haplic Cambisol in a natural area and with soil management in Alfredo Wagner - SC in the 0 to 5 and 5 to $10-\mathrm{cm}$ layers.

\begin{tabular}{|c|c|c|c|c|c|c|c|}
\hline \multirow{2}{*}{$\begin{array}{c}\text { Area/ } \\
\text { Management }\end{array}$} & \multirow{2}{*}{$\begin{array}{l}\text { Layer } \\
(\mathrm{cm})\end{array}$} & Class 1 & Class 2 & Class 3 & Class 4 & Class 5 & \multirow{2}{*}{$\begin{array}{l}\text { MWD } \\
(\mathrm{mm})\end{array}$} \\
\hline & & \multicolumn{5}{|c|}{ (\%) } & \\
\hline \multirow{2}{*}{ NTVPS } & $0-5$ & 72.0 & 9.8 & 3.3 & 8.9 & 6.0 & $5.0 \mathrm{a}$ \\
\hline & $5-10$ & 71.9 & 8.0 & 4.9 & 6.2 & 9.0 & $4.9 \mathrm{a}$ \\
\hline \multirow{2}{*}{ CT } & $0-5$ & 32.6 & 12.0 & 9.0 & 23.6 & 22.8 & $2.8 \mathrm{~b}$ \\
\hline & $5-10$ & 39.8 & 12.0 & 8.9 & 22.0 & 17.3 & $3.2 \mathrm{~b}$ \\
\hline \multirow{2}{*}{ NF } & $0-5$ & 66.4 & 10.3 & 3.5 & 3.4 & 16.3 & $4.6 \mathrm{a}$ \\
\hline & $5-10$ & 68.6 & 10.6 & 2.6 & 3.4 & 14.4 & $4.8 a$ \\
\hline Mean & & 58.5 & 10.4 & 5.4 & 11.3 & 14.3 & 4.2 \\
\hline CV (\%) & & 30.0 & 14.5 & 53.2 & 81.6 & 42.3 & 22.8 \\
\hline
\end{tabular}

Note: NTVPS: No-tillage vegetable planting system; CT: Conventional tillage; NF: Native forest; MWD: Mean weight-diameter. Class 1: 4.76mm, class 2: 2.00mm, class 3: 1.00mm, class 4: $0.25 \mathrm{~mm}$, class 5: what was not retained on the sieve. Different letters in each layer indicate difference by the Scott-Knott test at $5 \%$ significance.

Table 3. Physical attributes related to the structure of a Haplic Cambisol in a natural area and with soil management in Alfredo Wagner - SC in the 0 to 5 and 5 to 10 -cm layers.

\begin{tabular}{|c|c|c|c|c|c|c|c|}
\hline \multirow{2}{*}{$\begin{array}{c}\text { Area/ } \\
\text { Management }\end{array}$} & \multirow{2}{*}{$\begin{array}{l}\text { Layer } \\
(\mathrm{cm})\end{array}$} & \multirow{2}{*}{$\begin{array}{c}\mathrm{SD} \\
\left(\mathrm{g} \mathrm{cm}^{-3}\right)\end{array}$} & \multirow{2}{*}{$\begin{array}{c}\text { PR } \\
(\mathrm{MPa}) \\
\end{array}$} & FC & TP & Micro & Macro \\
\hline & & & & \multicolumn{4}{|c|}{$\left(m^{3} m^{-3}\right)$} \\
\hline \multirow{2}{*}{ NTVPS } & $0-5$ & $1.19 \mathrm{~b}$ & $2.40 a$ & $0.33 a$ & $0.51 b$ & $0.35 \mathrm{a}$ & $0.16 \mathrm{~b}$ \\
\hline & $5-10$ & $1.36 \mathrm{~b}$ & $3.82 \mathrm{a}$ & $0.38 a$ & $0.49 a b$ & $0.39 a$ & $0.10 \mathrm{~b}$ \\
\hline \multirow{2}{*}{$\mathrm{CT}$} & $0-5$ & $1.37 \mathrm{a}$ & $1.48 \mathrm{~b}$ & $0.37 a b$ & $0.53 b$ & $0.38 a b$ & $0.15 b$ \\
\hline & $5-10$ & $1.46 \mathrm{a}$ & $2.39 \mathrm{~b}$ & $0.36 a b$ & $0.50 \mathrm{~b}$ & $0.36 a b$ & $0.14 c$ \\
\hline \multirow{2}{*}{ NF } & $0-5$ & $0.84 \mathrm{c}$ & $0.55 \mathrm{c}$ & $0.30 \mathrm{~b}$ & $0.59 \mathrm{a}$ & $0.31 b$ & $0.28 a$ \\
\hline & $5-10$ & $0.92 c$ & $0.93 c$ & $0.35 b$ & $0.57 a$ & $0.36 \mathrm{~b}$ & $0.21 \mathrm{a}$ \\
\hline Mean & & 1.19 & 1.93 & 0.35 & 0.53 & 0.36 & 0.17 \\
\hline CV (\%) & & 21.52 & 61.92 & 8.59 & 7.58 & 7.64 & 37.10 \\
\hline
\end{tabular}

Note: Means followed by the same letter in the column, in each layer, do not differ by the Scott-Knott test at a $5 \%$ significance level; (SD) soil density; (PR) penetration resistance; (FC) field capacity; (TP) total porosity; (Micro) micropores; (Macro) macropores. 
Regarding the NTVPS and CT production areas, there were significant differences between treatments (Table 3 ) in $\mathrm{SD}, \mathrm{PR}$ and macroporosity in CT in the 5 to $10-\mathrm{cm}$ layer. The changes in soil structure shown as a result of soil preparation and disaggregation caused alterations in the soil-water-air relationship, which can directly affect plant production (Loss et al., 2017).

Soil use and management decrease total soil porosity with a reduction in the volume of macropores (Xu et al, 1992) associated with an increase in soil density (SD), which was $1.19 \mathrm{~g} \mathrm{~cm}^{-3}$ at $0-5 \mathrm{~cm}$ and $1.36 \mathrm{~g} \mathrm{~cm}^{-3}$ at $5-10 \mathrm{~cm}$ in NTVPS, and increased to $1.37 \mathrm{~g} \mathrm{~cm}^{-3}$ at $0-5 \mathrm{~cm}$ and $1.47 \mathrm{~g} \mathrm{~cm}^{-3}$ at 5 $10 \mathrm{~cm}$ in $\mathrm{CT}$, unlike the values found in NF, which were lower than $1.00 \mathrm{~g} \mathrm{~cm}^{-3}$ (Table 3).

The quantity of macropores in the three study areas remained higher than the limit of $0.10 \mathrm{~cm}^{3} \mathrm{~cm}^{-3}$ (Xu et al., 1992), which is an indication of soil quality for plant development. The volume of micropores was similar in NTVPS as compared to that in $\mathrm{CT}$, and in this system, it was equivalent to that in NF in both layers (Table 3).

Penetration resistance (PR) in NTVPS, at the two studied depths, was higher than the critical limit of $2 \mathrm{MPa}$ suggested by Taylor (1971) as indicative of the soil's physical quality. Despite this, the soil showed adequate values for macropores, and soil density did not exceed the values that indicate compaction, as shown in Table 3.

Water infiltration into the soil was higher in NTVPS (Figure 2) as compared to that in CT, where there was less. The soil's structural quality observed in NTVPS is evidenced by high water infiltration and aeration, as it showed greater water infiltration into the soil, which is an important factor from an agronomic and hydrological point of view.

However, in CT, low infiltration, although not followed by a reduction in macropores, can be related to the surface sealing observed in $\mathrm{CT}$, which results from the impact of raindrops falling directly onto the soil surface. The initial infiltration rate in NTVPS reached $107.7 \mathrm{~mm} \mathrm{~h}^{-1}$, while in the NF system, it was $51.2 \mathrm{~mm} \mathrm{~h}^{-1}$, and in $\mathrm{PC}, 21.6 \mathrm{~mm} \mathrm{~h}^{-1}$. The final rate in each area was $12.8 \mathrm{~mm} \mathrm{~h}^{-1}, 14.2 \mathrm{~mm} \mathrm{~h}^{-1}$ and $21.6 \mathrm{~mm} \mathrm{~h}^{-1}$, respectively (Figure 2).

The big difference found in NTVPS as compared to the other treatments was the soil moisture presented in each

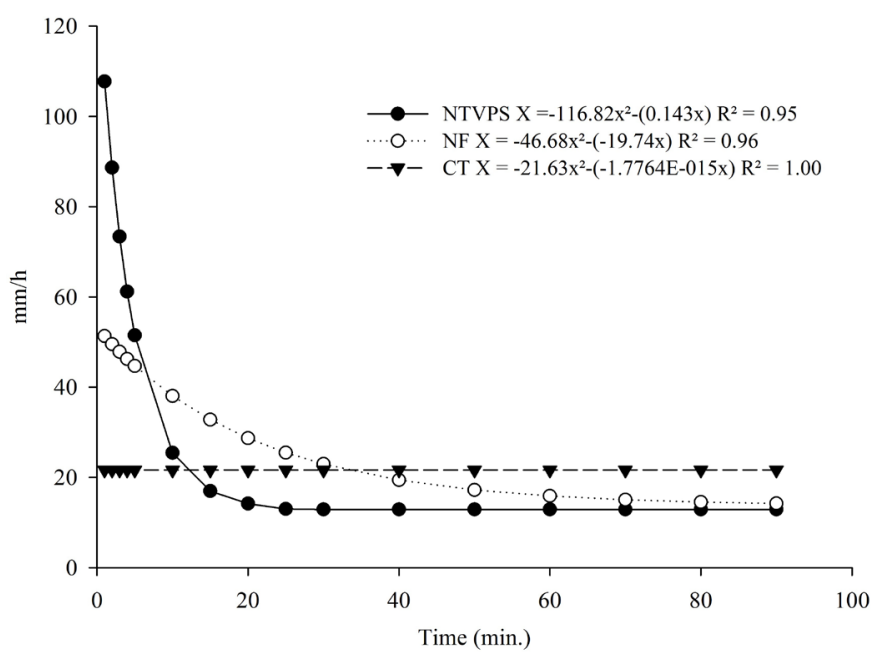

Figure 2. Water infiltration into the soil in NTVPS, NF and CT in Haplic Cambisol.

treatment, which was $11 \%$ in NTVPS, $9 \%$ in CT, and $16 \%$ in NF, considered low in all of them (Figure 2).

One possible explanation is the low rainfall that preceded the test, with a precipitation of $122 \mathrm{~mm}$ in the last 30 days (INMET, 2020). This is below the average for the period, which is $145 \mathrm{~mm}$ (INMET, 2020), and $16 \%$ less than the historical average.

A stabilization starting 20 minutes after the beginning of the infiltration test was also observed in NTVPS, which can be explained by the filling of soil particles with water, unlike what occurred in $\mathrm{CT}$, where infiltration was constant from the beginning of the test and low, which was different in NF, where water infiltration decreased throughout the test period.

Another point to be highlighted regarding the method using concentric rings by Forsythe (1975) is the overestimation caused by the use of such a test, as described by Bertol et al. (2001), which leads to higher absolute values, that is, overestimated values.

The high accumulation of phytomass in NTVPS, where a minimum phytomass production of 10 tons per hectare is recommended, can increase chemical fertility levels (Kurtz et al., 2019), as well as TOC and nutrient contents. In this regard, TOC content was higher in NTVPS as compared to that in CT, which is due to the addition of residues on the soil surface by the cover crops in the crop rotation system (Table 4).

Table 4. Organic carbon content and stocks and its grain-size fractions in onion-production areas (NTVPS and CT) and in a native forest (NF).

\begin{tabular}{|c|c|c|c|c|c|c|c|c|c|c|c|c|c|c|c|c|c|c|c|c|c|}
\hline \multirow{2}{*}{ Treat. } & \multirow{2}{*}{$\begin{array}{l}\text { Depth } \\
(\mathrm{cm})\end{array}$} & \multicolumn{2}{|c|}{ TOC } & \multirow{2}{*}{\multicolumn{2}{|c|}{$\frac{P O C}{\left(\mathrm{~g} \mathrm{~kg}^{-1}\right)}$}} & \multicolumn{2}{|c|}{ MAC } & \multicolumn{2}{|c|}{ sTOC } & \multirow{2}{*}{\multicolumn{2}{|c|}{$\frac{\text { sPOC }}{\left(\mathrm{Mg} \mathrm{ha}^{-1}\right)}$}} & \multicolumn{2}{|c|}{ sMAC } & \multicolumn{2}{|c|}{ CEI } & \multicolumn{2}{|l|}{$\mathbf{L}$} & \multicolumn{2}{|l|}{ LI } & \multicolumn{2}{|c|}{ CMI } \\
\hline & & & & & & & & & & & & & & & & & - & & & & \\
\hline \multirow{2}{*}{ NTVPS } & $0-5$ & 34.7 & $b$ & 18.5 & $b$ & 23.9 & $a$ & 25.1 & $b$ & 10.9 & $b$ & 14.2 & a & 0.7 & $b$ & 0.9 & $a$ & 0.3 & $b$ & 23 & $\bar{b}$ \\
\hline & $5-10$ & 31.9 & b & 13.9 & b & 22.6 & b & 24.7 & b & 9.4 & b & 15.4 & a & 0.6 & $b$ & 0.8 & b & 0.9 & b & 66.7 & b \\
\hline CT & $5-10$ & 26.5 & C & 6.5 & c & 20.4 & $b$ & 19.7 & $b$ & 4.7 & c & 15 & a & 0.5 & c & 0.4 & c & 0.4 & c & 19 & C \\
\hline NF & $0-5$ & 74 & a & 47.8 & a & 35.5 & a & 35.1 & $a$ & 20.3 & a & 15.1 & a & 1 & $a$ & 2.8 & a & 1 & a & 100 & a \\
\hline CV (\%) & & 47.1 & & 76.6 & & 29.2 & & 24.9 & & 55.2 & & 6.5 & & 35 & & 88.5 & & 59.3 & & 79.9 & \\
\hline
\end{tabular}

Note: Means followed by the same letter in the column do not differ by the Scott-Knott test at a 5\% significance level; TOC: Total organic carbon; sTOC: Total organic carbon stock; POC: Particulate organic carbon; MAM: Mineral-associated carbon; sMAC: Mineral-associated carbon stock; CEI: Carbon efficiency index; L: Lability; LI: Lability index; CMI: Carbon management index. 
The values found for soil TOC content, as shown in Table 4 , proved to be lower in commercial crops, such as in CT and NTVPS, compared to NF up to $10 \mathrm{~cm}$ in depth. The variation in the values found was high, from 25 to $74 \mathrm{~g} \mathrm{~kg}^{-1}$, with a decrease for the lower layers in NTVPS and NF, and an increase in depth in CT due to the soil reworking system at each cycle. The TOC values found in NF were substantially higher than in the other treatments, and the large variation occurring between one layer and another can also be observed, which is explained by the plant contribution on the soil surface.

TOC content (Table 4) in the commercial NTVPS crop ranged from 34.7 to $31.9 \mathrm{~g} \mathrm{~kg}^{-1}$, which was lower than that in NF, despite the use of different soil covers over 10 years of cultivation, with continuous phytomass and carbon input on the surface and in depth by the root system. CT over 30 years of intense soil disturbance favored disaggregation, with the release of the organic carbon protected in the macroaggregates through oxidation of organic compounds.

In the organic matter dynamics, it is also notable that TOC in native systems, such as NF, shows expressive values between the superficial layer and in depth, as reported in this study, in NF.

The expressive values found, when compared to the CT management system, was another response to the management adopted in NTVPS, namely, the use of intercropped and single cover plants for phytomass production to increase TOC (Comin et al., 2018).

It is noteworthy that species with deep roots, such as legumes, which are used in NTVPS systems, and other perennial crops found in NF have a wider root system along the soil profile. Thus rhizodeposition occurs, favoring $C$ input (Loss et al., 2020).

The highest $P O C$ values were found in in the $0-5-\mathrm{cm}$ layer in NF. The POC values found in NTVPS were higher than those in CT (Table 4), showing that the crop-rotation system adopted, with high phytomass production in the $0-5-\mathrm{cm}$ soil layer was able to increase the stocks in this fraction. In general, POC is sensitive to changes caused by management and its reduction in conventional tillage can be associated with lower biomass input and the fragmentation of aggregates (Loss et al., 2015).

In NTVPS, the higher COP levels can be explained by the species used in crop rotation over time, such as that of velvet beans, which have a high dry-matter production potential, besides the fact that its speed of growth and decomposition is less pronounced than that of other legumes (Pantaleão et al., 2012). In addition to physical effects, the biomass maintained in the cultivation environment provides nutrients and organic acids that are incorporated into the soil and can have allelopathic effects on other plant species (Queiroz et al., 2010).

Mineral-associated carbon (MAC) content (Table 3) was higher in NF, showing a higher capacity of the native system for $\mathrm{C}$ protection, followed by NTVPS and CT. The CT management showed lower MAC content, which can be explained by intense soil disturbance that consumes soil organic matter (SOM). The difference between the productive areas and the forest area lies in the composition and quality of the residues added to the soil, and the area of native vegetation is considered a reference to analyze the effects that the change in soil use and management can bring on SOM dynamics (Santos et al., 2018).

NF showed a higher total organic carbon stock (sTOC) than the other treatments in both layers studied, totaling $38.29 \mathrm{Mg}$ $\mathrm{ha}^{-1}$ in the 0 to $5-\mathrm{cm}$ layer and $31.79 \mathrm{Mg} \mathrm{ha}^{-1}$ in the 5 to $10-\mathrm{cm}$ layer. The high $C$ storage in native areas shows that, in wellpreserved environments, the influx of surface and subsurface $C$ into the soil is substantially greater, and the diversity of species present is a characteristic of these systems. CT and NTVPS showed lower STOC values as compared to NF, which indicates a possible $C$ loss in the two layers studied, especially when they are subjected to different soil use and management systems.

When comparing the cultivation systems with the natural system, it was found that the $\mathrm{C}$ stocks in the evaluated areas, at the depths of $0-5 \mathrm{~cm}$ and $5-10 \mathrm{~cm}$, were $28 \%$ and $22 \%$ lower for NTVPS, respectively, as compared to NF, while for CT, they were $46 \%$ lower at $0-5$ and $37 \%$ at $5-10 \mathrm{~cm}$.

The particulate carbon stock (sPOC) was higher in NF. Such a difference found in SPOC can be explained by the contribution from litter deposition in natural systems, and it shows that, in areas managed with crop rotation and the use of several species with a large contribution of cover material, such as in NTVPS, there is an increase in carbon stocks and consequently in granulometric fractions, as shown in Table 1.

The values for the mineral-associated carbon stock (sMAC) were similar for the areas, which can be explained by their greater protection, with a longer cycling time (Bayer et al., 2004). Thus, a longer period is required for management systems to change that fraction (Bayer et al., 2004).

Over time, continuous deposition favors the input of cover plant residues and, together with rhizodeposition, it favors sMAC increase at depth (Thivierge et al., 2016).

The carbon management index (CMI) was higher in NTVPS as compared to that in CT, but it was lower and statistically different from that in NF (reference). It showed a very low value especially in the $C T$ area, which had accumulated $C$ losses for 30 years, thus showing the soil degradation present in this type of management.

On the other hand, the CMI values found in NTVPS, which were higher than those found in $\mathrm{CT}$, despite the soil use for 10 years, indicate the capacity for soil under conservation management to recover. The carbon management indexes (CMI) in CT and NTVPS were lower than that in NF, which is considered the reference; therefore, when below 100, they indicate a lower $\mathrm{C}$ input and storage in the soil. CMI was sensitive in the comparative evaluation between the systems studied. Its lowest value was found in CT as compared to that in NTVPS, which shows its regeneration capacity. The lowest CMI value in $\mathrm{CT}$ indicates a negative impact of this management type on $\mathrm{C}$. 


\section{Conclusions}

NTVPS proved to be more efficient in carbon storage as compared to $\mathrm{CT}$, although it showed a smaller stock of that element when compared to the native environment.

NTVPS improved aggregation when compared to CT, and showed favorable structural conditions for plant growth, although it posed greater penetration resistance than did CT.

NTVPS showed better water infiltration conditions as compared to CT.

\section{Compliance with Ethical Standards}

Authors contributions: Conceptualization: DFR, ALM; Data curation: DFR, FFC, RMP, CPL; Formal analysis: DFR; Funding acquisition: ALM; Investigation: DFR, FFC, RMP, CPL, GK; Methodology: DFR, ALM; Project administration: DFR, ALM; Resources: DFR, ALM; Software: DFR, ALM; Supervision: ALM; Validation: DFR, ALM; Visualization: DFR, Writing - original draft: DFR, ALM, GK; Writing - review \& editing; DFR, ALM, GK.

Conflict of interests: The authors declare no conflict of interest.

Funding: Universidade do Estado de Santa Catarina (Research Support Program - PAD/UDESC) and Coordenação de Aperfeiçoamento de Pessoal de Nível Superior - Brasil (CAPES) - Finance Code 001.

\section{Literature Cited}

Arl, V.; Christoffoli, P. I.; Fayad, J. A. Sistema de plantio direto de hortaliças: sistema de plantio direto de hortaliças: Uma práxis da transição agroecológica com a agricultura familiar. In: Fayad, J.A.; Arl, V.; Comim, J.J.; Mafra, A.L.; Marchesi, D.R. (Orgs.). Sistema de plantio direto de hortaliças, 2019. v. 1, p. 39-54.

Bayer, C.; Martin-Neto, L.; Mielniczuk, J.; Pavinato, A. Armazenamento de carbono em frações lábeis da matéria orgânica de um Latossolo Vermelho sob plantio direto. Pesquisa Agropecuária Brasileira, v.39, n.7, p.677- 683, 2004. https://doi.org/10.1590/ S0100-204X2004000700009.

Bertol, I.; Beutler, F.J.; Leite, D.; Batistela, O. Propriedades físicas de um Cambissolo Húmico afetadas pelo tipo de manejo do solo. Scientia Agricola, v. 58, n. 3, p. 555-560, 2001. https://doi. org/10.1590/S0103-90162001000300018.

Blair, G.; Lefroy, R.D.B.; Lisle, L. Soil carbon fractions based on their degree of oxidation, and the development of a carbon management index for agricultural systems. Australian Journal of Agricultural Research, v.46, n.7, p.1459-1466, 1995. https://doi. org/10.1071/AR9951459.

Blake, G.R.; Hartge, K.H. Bulk density. In: In: Klute, A. Methods of soil analysis: Part 1 - Physical and mineralogical methods, 5.1. 2.ed. Madison: American Society of Agronomy, 1986. Chap 13, p.363375. https://doi.org/10.2136/sssabookser5.1.2ed.c13.

Cambardella, C.A.; Elliott, E.T. Particulate soil organic-matter changes across a grassland cultivation sequence. Soil Science Society of America Journal, v.56, n.3, p.777-783, 1992. https://doi. org/10.2136/sssaj1992.03615995005600030017x.
Claessen, M.E.C.; Barreto, W. de O.; Paula, J.L.; Duarte, M.N. Manual de métodos de análises de solo. Rio de Janeiro: Embrapa, 1997. $212 p$.

Comin, J.J.; Ferreira, L.; Dos Santos, L.; Koucher, L.; Machado, L. M.; Dos Santos Junior, E.; Mafra, Á. L.; Kurtz, C.; Souza, M.; Brunetto, G.; Loss, A. Carbon and nitrogen contents and aggregation index of soil cultivated with onion for seven years using crop successions and rotations. Soil and Tillage Research, v.184, p.195-202. 2018. https://doi.org/10.1016/j.still.2018.08.002.

Day, P.R. Particle fractionation and particle-size analysis. In: Black, C. A.; Evans. D. D.; White, J. L.; Ensminger, L. E.; Clark, F. E. (Eds.). Methods of soil analysis: Part 1 - Physical and mineralogical properties, including statistics of measurement and sampling, 9.1. Madison: American Society of Agronomy, 1965. Chap. 43, p.545-566. (Agronomy Monographs, 9). https://doi.org/10.2134/ agronmonogr9.1.c43.

Forsythe, W. Fisica de suelos; Manual de laboratório. New York: University Press, 1975. 324p.

Freitas, P.L.; Harmonia com a natureza: a adoção do sistema de plantio direto pode garantir competitividade à agricultura brasileira, em especial na região dos cerrados. Agroanalysis, v. 22, n.2, p. 12-17, 2002. http://bibliotecadigital.fgv.br/ojs/index.php/agroanalysis/ article/view/50478/49282. 02 Aug. 2020.

Gee, G.W.; Bauder, J. W. Particle-size analysis. In: Klute, A. Methods of soil analysis: Part 1 - Physical and mineralogical methods, 5.1. 2.ed. Madison: American Society of Agronomy, 1986. Chap 15, p. 383-411. (Agronomy Monographs, 9). https://doi.org/10.2136/ sssabookser5.1.2ed.c15.

Guareschi, R.F.; Pereira, M.G.; Perin, A. Estoque de carbono em Latossolo Vermelho Distroférrico sob diferentes sistemas de manejo. Revista Brasileira de Ciências Agrárias, v.7, n.4, p.597602, 2012. https://doi.org/10.5039/agraria.v7i4a1767.

Gugel, J.T.; Cebola. In: Empresa de Pesquisa Agropecuária e Extensão Rural de Santa Catarina - Epagri, Centro de Socioeconomia e Planejamento Agrícola - Cepa. Síntese anual da agricultura de Santa Catarina 2016-2017. Florianópolis: Epagri; Cepa, 2018. p. 47-52. https://docweb.epagri.sc.gov.br/website_cepa/ publicacoes/Sintese_2016_17_site.pdf. 02 Aug. 2020.

Instituto Nacional de Meteorologia - INMET. Dados meteorológicos. Alfredo Wagner-SC. https://portal.inmet.gov.br. 10 Apr. 2020.

Jordán, A.; Zavala, L.; Gil, J. Effects of mulching on soil physical properties and runoff under semi-arid conditions in Southern Spain. Catena, v.81, n.1, p.77-85, 2010. https://doi.org/10.1016/j. catena.2010.01.007.

Kemper, W.D.; Chepil, W.S. Size distribution of aggregates. Black, C. A.; Evans. D. D.; White, J. L.; Ensminger, L. E.; Clark, F. E. (Eds.). Methods of soil analysis: Part 1 - Physical and mineralogical properties, including statistics of measurement and sampling, 9.1. Madison: American Society of Agronomy, 1965. Chap. 39, p.499-510. (Agronomy Monographs, 9). https://doi:10.2134/ agronmonogr9.1.c39.

Kurtz, C.; Lourenzi, C.R.; Higashikawa, F.S.; Brunetto, G.; Gatiboni, L.C. Conceito de fertilidade em SPDH. In: Fayad, J.A.; Arl, V.; Comim, J.J.; Mafra, A.L.; Marchesi, D.R. (Orgs.). Sistema de plantio direto de hortaliças. São Paulo: Expressão Popular, 2019. v.1, p.85-103. 
Loss, A.; Basso, A.; Oliveira, B.S.; De Paula Koucher, L.; De Oliveira, R.A.; Kurtz, C.; Comin, J.J. Carbono orgânico total e agregação do solo em sistema de plantio direto agroecológico e convencional de cebola. Revista Brasileira de Ciência do Solo, v.39, n.4, p.12121224, 2015. https://doi.org/10.1590/01000683rbcs20140718.

Loss, A.; dos Santos Junior, E.; Schmitz, D.; Da Veiga, M.; Kurtz, C.; Comin, J.J. Atributos físicos do solo em cultivo de cebola sob sistemas de plantio direto e preparo convencional. Revista Colombiana de Ciencias Hortícolas, v.11, n.1, p.105-113, 2017. https://doi.org/10.17584/rcch.2017v11i1.6144.

Loss, A.; Ferreira, L.B.; Gonzatto, R.; Giumbelli, L.D.; Mafra, Á.L.; Goedel, A. Efeito da sucessão ou rotação de culturas sobre a fertilidade do solo após sete anos de cultivo com cebola. Brazilian Journal of Development, v.6, n.3, p. 16587-16606, 2020. https:// doi.org/10.34117/bjdv6n3-507.

Lovato, T.; Mielniczuk, J.; Bayer, C.; Vezzani, C. Adição de carbono e nitrogênio e sua relação com os estoques no solo e com o rendimento do milho em sistemas de manejo. Revista Brasileira de Ciência do Solo, v.28, n.1, p.175-87, 2004. https://doi. org/10.1590/S0100-06832004000100017

Mafra, A.L.; Comin, J.J.; Lana, M.A.; Bittencourt, H.V.H.; Lovato, P.E.; Wildner, L.P. Iniciando o sistema de plantio direto de hortaliças: Adequações do solo e práticas de cultivo. In: Fayad, J.A.; Arl, V.; Comim, J.J.; Mafra, A.L.; Marchesi, D.R. (Orgs.). Sistema de plantio direto de hortaliças. São Paulo: Expressão Popular, 2019. v.1, p.215-226.

Melo, T.R.; Pereira, M.G.; Barbosa, G.M.C.; Silva Neto, E.C.; Andrello, A.C.; Tavares Filho, J. Biogenic aggregation intensifies soil improvement caused by manures. Soil and Tillage Research, v.190, p.186-193, 2019. https://doi.org/10.1016/j.still.2018.12.017.

Nicholls, C.I.; Altieri, M.Á.; Vazquez, L.; Ventura, G.W.; Ferreira, G.W.; Comin, J.J. Sistema plantio direto de hortaliças: princípios de transição para sistemas de produção ecológicos e redesenho de propriedades familiares. In: Fayad, J.A.; Arl, V.; Comim, J.J.; Mafra, A.L.; Marchesi, D.R. (Orgs.). Sistema de plantio direto de hortaliças. São Paulo: Expressão Popular, 2019. v.1, p. 39-52.

Pantaleão, P. S.; Laca-Buendía, J. P.; Brito, L.F., Godinho, N.C.A.; Bernardes, A.G. Supressão de plantas daninhas pela cobertura com adubos verdes em solo de Cerrado. FAZU em Revista, v.1, n. 9, p. 30-43, 2012.
Patra, S.; Julich, S.; Feger, K.H.; Jat, M.L.; Jat, H.; Sharma, P.C.; Schwärzel, K. Soil hydraulic response to conservation agriculture under irrigated intensive cereal-based cropping systems in a semiarid climate. Soil and Tillage Research, v.192, p.151-163, 2019. https:// doi.org/10.1016/j.still.2019.05.003.

Prevedello, C. L. Física do solo com problemas resolvidos. Curitiba: SAEAFS, 1996. 446p.

Queiroz, L. R.; Galvão, J. C. C.; Cruz, J. C.; Oliveira, M. F.; Tardin, F. D. Supressão de plantas daninhas e produção de milho-verde orgânico em sistema de plantio direto. Planta Daninha, v. 28, n. 2, p. 263270, 2010. https://doi.org/10.1590/S0100-83582010000200005.

Santos, L.H.; Loss, A.; Lourenzi, C.R.; Souza, M.; Gonzatto, R.; Kurtz, C.; Brunetto, G.; Comin, J.J. Total nitrogen and humic substances in aggregates of soils with onion crops under no-tillage and conventional tillage systems. Revista Colombiana de Ciencias Horticolas, v.12, n.1, p.166-174, 2018. https://doi.org/10.17584/ rcch.2018v12i1.7339.

Scott, A.; Knott, M. Cluster-analysis method for grouping means in analysis of variance. Biometrics, v.30, n.3, p.507-512, 1974. https://doi.org/10.2307/2529204.

Sokal, R.R.; Rohlf, F.J. Biometry. 3.ed. New York: W.H. Freeman, 1995. $887 p$.

Taylor, H.M. Effect of soil strength on seedling emergence, root growth and crop yield. In: Barnes, K.K. (Ed.) Compaction of agricultural soils. Madison: American Society of Agricultural Engineers, 1971. p.292-305.

Thivierge, M.N.; Jégo, G.; Bélanger, G.; Bertrand, A.; Tremblay, G.F.;Alan Rotz, C.; Qian, B. Predicted yield and nutritive value of an alfalfatimothy mixture under climate change and elevated atmospheric carbon dioxide. Agronomy Journal, v.108, n.2, p.585-603, 2016. https://doi.org/10.2134/agronj2015.0484.

Vieira, F.C.B.; Bayer, C.; Zanatta, J.A.; Dieckow, J.; Mielniczuk, J.; He, Z.L. Carbon management index based on physical fractionation of soil matter in an Acrisol under long-term no-till cropping systems. Soil and Tillage Research, v.96, n.1-2, p.195-204, oct. 2007. https://doi. org/10.1016/j.still.2007.06.007.

$\mathrm{Xu}, \mathrm{X}$.; Nieber, J.L.; Gupta, S.C. Compaction effect on the gas diffusion coefficient in soils. Soil Science Society of America Journal, v.56, n.6, p.1743-1750, 1992. https://doi.org/10.2136/sssaj1992.03615 995005600060014x. 